\title{
SONDAGENS TOVS: IMPACTO NA ANÁLISE SINÓTICA ENTRE 18 E 19 DE MARÇO DE 1991 NA REGIÃO SUL E SUDESTE DO BRASIL.
}

\author{
Jojhy Sakuragi
}

Dissertação de Mestrado em Meteorologia, orientadores: Dra. Marlene Elias Ferreira e Dr. Pedro Leite da Silva Dias, aprovada em 18 de dezembro de 1992 (INPE/MCT).

Este trabalho apresenta um estudo sobre o impacto dos perfis verticais de temperatura e de umidade. estimados a partir de radiâncias obtidas pelo TIROS Operational Vertical Sounder (TOVS), nos resultados gerados por um modelo diagnóstico de análise sinóptica sobre a região Sul e Sudeste do Brasil. O processamento das radiâncias do TOVS, sondador que opera a bordo dos satélites meteorológicos de órbita polar da série TIROS-N/NOAA, foi feito utilizando o International TOVS Processing Package-4 (ITPP-4), análises numéricas do National Meteorological Center (NMC) e dados meteorológicos convencionais. A partir dos perfis verticais de temperatura e de umidade obtidos inicialmente, foram gerados campos de temperatura, altura geopotencial, água precipitável, índice de instabilidade e advecções de temperatura e de umidade nos níveis-padrão de pressão. Esses campos foram utilizados no estudo de um caso de chuvas intensas ocorridas no dia 19 de março de 1991, na Grande São Paulo e na região litorânea. Os resultados foram comparados com as análises do NMC e com a situação meteorológica observada nas imagens de satélite. Com base nos resultados, conclue-se que, em geral, o impacto dos dados de satélite é positivo, especialmente pela disponibilidade de dados na região oceânica e pela alta resolução, tanto espacial como temporal. Verifica-se também que há boa concordância entre os resultados TOVS e a situação meteorológica observada nas imagens de satélite.
TOVS SOUNDINGS: IMPACT ON THE SYNOPTIC ANALYSIS OVER THE SOUTH AND SOUTHEAST REGIONS OF BRAZIL FROM MARCH 18 TO MARCH 19, 1991-This report explores the impact of temperature and humidity profiles retrieved from radiances obtained by TIROS Operational Vertical Sounder (TOVS) on the synoptic analysis over South and Southeast of Brazil. The radiance data obtained by the TOVS sounder which operates on board of the TIROS-N/NOAA polar orbiting meteorological satellites, were processed with the aid of the International TOVS Processing Package-4 (ITPP-4), numerical analyses from National Meteorological Center $(N M C)$ and conventional meteorological data. From the temperature and humidity profiles initially obtained, temperature, geopotential height, precipitable water, instability index and advection fields were generated at constant pressure levels. A case study of the occurrence of intense precipitation during 19 March, 1991, in the Greater São Paulo and nearby coastal regions was so formed. The results were compared with the NMC analyses and the meteorological conditions observed in the satellite imagery. Based on these results, it is generally concluded that the impact of satellite data is positive, especially due to its availability over the oceanic regions, and by the high spatial resolution and high temporal frequency. The good agreement between the TOVS results and the observed meteorological conditions from satellite images supports this conclusion.

\section{BALANÇO DE RADIAÇÃO EM TRÊS ECOSSISTEMAS DA FLORESTA AMA- ZÔNICA: CAMPINA, CAMPINARANA E MATA DENSA}

\author{
Mário de Miranda Vilas Boas Ramos Leitão
}

Tese de Doutorado em Meterologia, aprovada em 07 de outubro de 1994, orientada pelo Dr. Jesus Marden dos Santos (INPE/MCT).

Analisam-se fluxos de radiação em três ecossistemas amazônicos: Campina e Campinarana localizados na Estação Experimental da Silvicultura Tropical ( $\left.2^{\circ} 34^{\prime} \mathrm{S} ; 60^{\circ} 2^{\prime} \mathrm{W}\right)$ e Mata densa situado na Reserva Florestal Ducke ( $2^{\circ} \quad 57^{\prime} \mathrm{S} ; 59^{\circ}$ $\left.57^{\prime} \mathrm{W}\right)$, para os períodos setembro de 1991e agosto / setembro de 1993. Foram instalados em cada área de estudo no topo de uma torre, um conjunto de equipamentos composto por piranômetros para medir os fluxos de radiação de onda
RADIATION BALANCE IN THREE AMAZONIAN ECOSYSTEMS: “CAMPINA", “CAMPINARANA" AND “MATA DENSA"-The radiation fluxes in three amazonian ecosystems are analised: "campina" and "campinarana" localized at "Estação Experimental de Silvicultura Tropical” (2034'S; 60'2'W) and "mata densa” at "Reserva Florestal Ducke” (20 57’ S; 59 57’W) on September/1991 and August/September 1993. In each 
curta e infravermelha incidentes e refletidos, além de um saldo radiômetro. Próximos à superfície do solo, sob os dosséis, foram usados 16 radiômetros para medir radiação de ondas curtas incidentes, 16 para medir radiação de ondas curtas refletida e 16 para medir radiação fotossinteticamente ativa (PAR). A aquisição dos dados foi efetuada com dois "microloggers" $21 \mathrm{X}$ e dois CR-10, que possibilitam obter-se médias de 1 minuto a partir de valores amostrados de 3 em 3 segundos entre 5:50 e 18:00 h, para todos os parâmetros observados. Nos 16 pontos de observação de radiação, tomaram-se fotografias hemisféricas, utilizando-se uma câmara Nikon equipada com lente olho de peixe de $8 \mathrm{~mm}$. Em complementação às medidas de radiação foi determinada a quantidade de Sunflecks. Avaliaramse de forma detalhada a atuação dos componentes do balanço de radiação e a aplicação da metodologia proposta por Steege (1994), que permite estimativas de índices de vegetação e de parâmetros climáticos através da interpretação de fotografias hemisféricas. Constatou-se não existir diferenças entre o albedo de ondas curtas dos três dosséis: campinarana $(10,4 \%)$, mata densa e campina $(11,3 \%)$. Quanto ao albedo na faixa do visível, na campinarana foi de $1,5 \%$, na campina $1,4 \%$ e na mata densa $2,0 \%$; já o albedo na faixa espectral do infravermelho próximo, na campinarana foi de $20,2 \%$, na mata densa $21,2 \%$ e na campina $22,0 \%$. Verificou-se que na base do dossel de campina chega 5 vezes mais radiação de ondas curtas e infravermelha, e 6 vezes mais PAR que na base do dossel de mata densa. As medidas de radiação na base dos dosséis apresentam grande variação espacial e temporal. Equações obtidas mostram que o albedo modelado em função do ângulo de elevação do Sol, e os saldos de radiação de ondas longas, estimados em função da radiação de ondas curtas incidente, apresentam ótima precisão. Constatou-se, ainda, que a utilização da metodologia de interpretação de fotografias hemisféricas representa uma ferramenta muito importante nos estudos de regeneração dentro de dosséis, pois além de proporcionar estimativas de parâmetros climáticos, tem a vantagem de possibilitar determinações de parâmetros como o índice de área foliar (LAI) e a cobertura do dossel sem destruí-lo. study area on top of a tower, a set of equipments composed of pyranometers to measure the incident and reflected shortwave and infrared radiation fluxes, besides a net radiometer were installed. Next to the soil's surface, under the canopy, 16 radiometers to measure incident shortwave radiation, 16 to measure reflected short-wave radiation and 16 to measure photosynthetic active radiation (PAR) were used. The acquisition of the data was made using two $21 X$ and one CR-10 microloggers, which allowed the obtaining of one-minute averages from values sampled every 3 seconds from 5:50 to 18:00 h, for all the observed parameters. At the 16 radiation observation points, hemispheric photographs were taken, using a Nikon camera equipped with a fish eye $8 \mathrm{~mm}$ lens. Complementing the radiation measurements, the quantity of sunflecks was determined. The behaviour of the radiation balance components and the application of Steege's proposed method (1994), which permits vegetation indexes and climatic parameters estimation through the interpretation of hemispheric photographs were examined in detail. No differences between the short-wave albedo of the three canopies ("campinarana"-10.4\%, "mata densa" and "campina" $11.3 \%)$ were noted. The visible-range's albedo was 1.5 , 1.4 and $2 \%$ at the "campinarana", "campina" and "mata densa", respectively, while the near infrared spectral range's albedo was 20.2, 22 and $21.2 \%$ at the "campinarana", "campina" and "mata densa", respectively. At the basis of the canopy of the "campina it was verified that 5 times more short-wave and infrared radiation is received, and 6 times more PAR, than at the basis of the canopy of "mata densa". The radiation measurements at the basis of the canopies showed great spatial and temporal variation. Equations obtained show that the albedo modelled in terms of the sun's elevation angle, and the radiation and longwave radiation's balance estimated in terms of the incident short-wave radiation have an excellent accuracy. Finally, the use of the hemispheric photographies interpretation method is a very important tool in the study of regeneration inside canopies because, apart from allowing estimations of climatic parameters, it has the advantage of permitting the non destructive determination of parameters such as canopies leaf area index (LAI) and

\section{CAMADA LIMITE AMAZÔNICA: ASPECTOS OBSERVACIONAIS E DE MODELAGEM}

Gilberto Fisch

Tese de Doutorado em Meteorologia, orientada pelo Dr. Carlos Afonso Nobre, aprovada em 13 de dezembro de 1995 (INPE/MCT).

Neste trabalho foram realizados estudos relativos à dinâmica da formação e evolução da Camada Limite Atmosférica (CLA) desenvolvidas sobre regiões de floresta tropical e área desmatada, na área de Ji-Paraná, no sudoeste da Amazônia.
AMAZONIAN BOUNDARY LAYER: NUMERICAL AND OBSERVACIONAL ASPECTS-The dynamics of the Atmospheric Boundary Layer ( $A B L)$ developed over tropical forest and deforested areas (pastures) have been studied, at Ji-Parand area in the southwest of Amaz6nia. 
Estas análises foram realizadas com dados observados de radiossondagem, balão cativo e fluxos turbulentos de superfícies coletadas em dois sítios experimentais, durante a realização do Experimento de Camada Limite de Rondônia (RBLE) nas épocas secas de 1993 e 1994. A Camada Limite Noturna (CLN) desenvolvida sobre pastagem (230-250 m) devido à sua maior rugosidade e turbulência mecânica. Como conseqüência deste fato, a intensidade da inversão térmica da superfície na pastagem (tipicamente de 45-50 $\mathrm{K} . \mathrm{km}^{-1}$ ) é superior ao da floresta (23-30 K. $\left.\mathrm{km}^{-1}\right)$. Durante o dia, o crescimento da Camada Limite Convectiva (CLC) sobre a pastagem (da ordem de 2000-2200 m) é aproximadamente $1000 \mathrm{~m}$ maior do que sobre floresta, uma vez que o primeiro possui uma maior taxa de liberação de calor sensível para a atmosfera. O crescimento da CLN e CLC foi estudado usando modelos numéricos uni-dimensionais. A modelagem uni-dimensional da CLN foi baseada em um modelo prognóstico de desenvolvimento da inversão térmica (Yamada, 1979). Os resultados obtidos ajustaram-se melhor aos pontos observacionais na área de pastagem do que sobre a floresta, embora subestimados: para os dados do RBLE 3 o modelo simulou uma altura final da CLN de $203 \mathrm{~m}$ para valor observacional de $230 \mathrm{~m}$. Na floresta, a diferença ente as alturas observada e calculada foi de 149 $\mathrm{m}$, provavelmente devido ao fato da estacionaridade do processo ocorrer na pastagem mais cedo do que na floresta. Resultado da sensibilidade do modelo mostraram que o resfriamento noturno da superfície é mais importante do que a divergência do fluxo de energia para o crescimento da CLN. No caso da CLC, um sistema de equações prognósticas, baseado na teoria desenvolvida por Tennekes (1973) foi desenvolvido, descrevendo a altura, a temperatura potencial virtual média da camada e a intensidade da descontinuidade térmica no topo da CLC e simulado com os dados do RBLE 2 e RBLE 3. Os resultados mostraram que o modelo subestima os valores observacionais da altura da CLC e que esta diferença é maior na pastagem do que na floresta. A temperatura potencial média estimada pelo modelo superestima os valores observacionais e esta diferença é de aproximadamente $0,5 \mathrm{~K}$ na floresta e $1,5 \mathrm{~K}$ na pastagem. A pouca habilidade do modelo em representar o crescimento da CLC, principalmente na pastagem, é devido à circulação térmica secundária (brisa de floresta) originada pela disposição de linhas de remanescentes de floresta tropical inseridas em áreas de pastagem, alterando o balanço de energia da superfície e a erosão da CLN. Esta brisa foi simulada usando um modelo numérico bi-dimensional de mesoescala (The Regional Atmospheric Modeling System -RAMS) e seu sinal observado, através da intensificação do vento horizontal e de células convectivas. A estimativa da energia advectada nesta situação no inicio da manhã é de $0,07 \mathrm{Kms}^{-1}$, a qual é da mesma ordem de magnitude dos fluxos turbulentos de superfície medidos.
Two field experiments (Rondônia Boundary Layer Experiment - RBLE) using radiosondes, tethered balloon and turbulent surface fluxes at both experimental sites have been conducted during the dry season of 1993 and 1994 and this data-set is an unique opportunity to compare the structure and evolution of ABL developed over forest and pasture. The Nocturnal Boundary Layer (NBL) developed over forest (typically around 350-380 m) is deeper than over pasture $(230-250 \mathrm{~m})$ due its higher roughness and mechanical turbulence. As a consequence, the strength of thermal inversion is stronger at pasture (typically about 45-

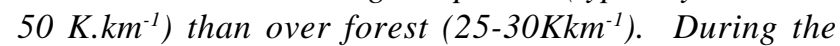
daytime, the growth of Convective Boundary Layer (CBL) over pasture (typically about 2000-2200 m) is about 1000 $m$ higher than over forest, as the former has a higher sensible heat flux to the atmosphere. The growth of NBL and CBL has been studied using uni and bidimensional models. The 1-D analyses of NBL were based on a prognostic model of thermal inversion (Yamada, 1979). The results obtained were better in the pasture than over forest, although underestimated: for RBLE 3 data the model simulated a height of $203 \mathrm{~m}$ for pasture similar to the observed height of $230 \mathrm{~m}$. At forest, the difference between the observed and calculated heights was increased to $149 \mathrm{~m}$, probably because the stationarity is reached first at pasture. Sensitivity analysis showed that the surface nocturnal cooling is more important than the divergence of turbulent flux for growth of the NBL. For CBL, a system of prognostic equations, based on the theory developed by Tennekes (1973), which describes the height, the average virtual potential temperature and the intensity of thermal discontinuity at the top of $C B L$ as derived and simulated for RBLE 2 and RBLE 3 data-set. The results have shown that the model underestimated the observations and this difference is higher over pasture than at forest. The average potential temperature estimated by the model has presented a tendency to calculate higher values than $0.5 \mathrm{~K}$ over forest and $1.5 \mathrm{~K}$ over pasture. The inaccuracy of the model to represent the growth of CBL, mainly at pasture, is due to a kind of secondary thermal circulation (forest breeze), triggered by patches of remaining forest inside pasture area, which alters the heat budget at the surface and the erosion of NBL. This breeze has been simulated using a 2-D ( $x-z$ domain) mesoscale model (The Regional Atmospheric Modeling System - RAMS) and its signal has been observed, throughout the intensification of horizontal wind and convective cells. The estimates of energy advection at this designed scenarious at mid-morning yields an energy flux of $0.07 \mathrm{Kms}^{-1}$, which has the same order of magnitude of the measured surface turbulent flux data. 


\title{
DISTÚRBIOS NOS VENTOS DE LESTE NO ATLÂNTICO TROPICAL
}

\author{
Elizabeth Silvestre Espinoza
}

Dissertação de Mestrado em Meteorologia, orientada pela Dra. Mary Toshie Kayano, aprovada em 06 de março de 1996 (INPE/MCT)

As técnicas das Funções Ortogonais Empíricas (EOF) e das Funções Ortogonais Empíricas Estendidas (EEOF) foram aplicadas na componente meridional do vento para investigar as características dos distúrbios ondulatórios de leste no Atlântico Tropical, para o período de 1 de janeiro de 1980 a 31 de dezembro de 1989 nos níveis de $1000 \mathrm{hPa}, 850 \mathrm{hPa}$, $700 \mathrm{hPa}$ e $500 \mathrm{hPa}$. Os padrões mostram a existência de distúrbios deslocando-se para oeste durante todo o ano mas com características sazonais diferentes. Durante DJF os distúrbios são mais intensos no Hemisfério Sul sendo o comprimento de onda de $6000 \mathrm{~km}$ a $7000 \mathrm{~km}$ e velocidade de fase de $10 \mathrm{~m} / \mathrm{s}$ a $14 \mathrm{~m} / \mathrm{s}$. Durante JJA os distúrbios são mais intensos no Hemisfério Norte, sendo o comprimento de onda de $3500 \mathrm{~km}$ a $4000 \mathrm{~km}$ e velocidade de fase de $10 \mathrm{~m} / \mathrm{s}$ a 13 $\mathrm{m} / \mathrm{s}$. Nas estações de transição (SON e MAM) estes distúrbios apresentam sinais tanto no Hemisfério Sul como no Hemisfério Norte. Dentre algumas características destes distúrbios, a inclinação horizontal é de sudeste para noroeste durante SON e DJF e é de sudoeste para nordeste durante MAM e JJA. Na vertical a inclinação é ligeiramente para leste durante SON e DJF, e é para leste de $1000 \mathrm{hPa}$ até 700 $\mathrm{hPa}$ e ara oeste de $700 \mathrm{hPa}$ até $500 \mathrm{hPa}$ durante MAM e JJA. os distúrbios de leste apresentam suas máximas intensidades no nível de 850 hPa. Foram encontrados indicações que estes distúrbios poderiam estar relacionados com os furacões do Hemisfério Norte durante JJA e SON. Nestes períodos a trajetória dos distúrbios é próxima daquela dos furacões.
EASTERLY DISTURBANCES IN THE TROPICAL ATLANTIC-The empirical orthogonal function and extended empirical orthogonal function techniques have been applied to the meridional wind component to investigate the features of the wavelike easterly disturbances in the Tropical Atlantic for the period January 1, 1980 to December 31, 1989 at $1000 \mathrm{hPa}, 850 \mathrm{hPa}, 700 \mathrm{hPa}$ e $500 \mathrm{hPa}$. The patterns show the existence of westward traveling disturbances during all the year with different seasonal features. During DJF the disturbances are more intense in the Southern Hemisphere, being the wavelength of $6000 \mathrm{~km}$ to $7000 \mathrm{~km}$ and phase velocity of $10 \mathrm{~m} / \mathrm{s}$ to $14 \mathrm{~m} / \mathrm{s}$. During JJA the disturbances are more intense in the Northern Hemisphere, being the wavelength of $3500 \mathrm{~km}$ to $4000 \mathrm{~km}$ and phase velocity of $10 \mathrm{~m} / \mathrm{s}$ to $13 \mathrm{~m} / \mathrm{s}$. During transition seasons (SON and MAM) these disturbances show signals in the Southern Hemisphere and in the Northern Hemisphere. Among some features of these disturbances, the horizontal inclination is from southeast to northwest during SON and $D J F$ and it is from southwest to northeast during MAM and $J J A$. The vertical inclination is slightly to east during SON and DJF and it is to east from $1000 \mathrm{hPa}$ to $700 \mathrm{hPa}$ and to west from $700 \mathrm{hPa}$ to $500 \mathrm{hPa}$ during MAM and JJA. The easterly disturbances show their maximum intensity at 850 hPa. Indications that these disturbances can be related to the hurricanes of Northern Hemisphere during JJA and SON, have been found. The trajectory of the travelling disturbances is close to the hurricane trajectory.

\section{MANUTENÇÃO DA CIRCULAÇÃO ATMOSFÉRICA SOBRE A AMÉRICA DO SUL}

\author{
Marley Cavalcante de Lima
}

\author{
Tese de Doutorado em Meteorologia, orientada pelo Dr. Vadlamudi \\ Brahmananda Rao, aprovada em abril de 1996 (INPE/MCT).
}

A manutenção da circulação atmosférica no verão sobre a América do Sul é estudada do ponto de vista dos balanços de vorticidade e de energia cinética. Considerou-se 5 anos de dados analisados diários (1 nov. 1985 - 31 jan. 1991), globais, obtidos do NMC, as 12 UTC. O balanço de vorticidade incluindo os transientes não foi muito definido. O balanço de energia cinética mostrou que o ciclo de energia sobre a América do Sul, no verão, se dá da seguinte forma: EPD para $K_{c}$, através do termo $-c \tilde{N}^{2} f$ e, de $K_{c}$ para $\mathrm{K}_{\mathrm{y}}$, principalmente através do termo de interação $f \tilde{\mathrm{N}}_{\mathrm{y}} \tilde{\mathrm{N}}_{c}$.
THE MAINTENANCE OF ATMOSPHERIC CIRCULATION OVER SOUTH AMERICA-The maintenance of summer atmospheric circulation over South America is studied from the point of view of balance of vorticity and kinetic energy. Five years of daily global NMC data (1 Nov. 1985- 31 Jan. 1991) at 12 UTC are used. The balance of vorticity including the transients was not well defined. The balance of kinetic energy showed that the energy cycle over South America during the summer is: EPD for $K_{C}$ through the term - $C \tilde{N}{ }^{2} f$ and, $K_{C}$ for $K_{Y}$ mainly 
O estudo de periodicidades nos parâmetros de energia cinética mostrou vários tipos de oscilações: o ciclo anual, de 30-60 dias e oscilações de curto período, sugerindo a presença de transientes. $\mathrm{Na}$ América dos Sul as interações entre as escalas sazonal e a intrasazonal foram mais dominantes. A enegia cinética local mostrou o papel dos transientes na região do Cavado sobre o Atlântico Sul e das interações sazonais e intrasazonais na região da Alta da Bolívia. Maiores interações ocorreram próximo ou na região das Zonas de Convergência do Atlântico Sul (ZCAS). through the term $f \tilde{N}_{Y} \tilde{N}_{C}$.An examination of the periodicities in the energy parameters shows several oscillations annual cycle, 30-60 days oscillations, and show short period oscillations suggesting the presence of transients. Over South America the interactions between seasonal and intraseasonal variations were more dominants. The local kinetic energy balance showed the role of the transients in the region of trough over South Atlantic. Over Bolivian High the interaction between seasonal and intraseasonal variations are important. Large interactions occur near the region of South Atlantic Convergence Zone (ZCAS).

\title{
BLOQUEIO ATMOSFÉRICO NO HEMISFÉRIO SUL
}

\section{Rosa de Fátima Cruz Marques}

\author{
Tese de Doutorado em Meteorologia, orientada pelo Dr. Vadlamudi Brahamanda Rao, aprovada em 14 \\ de outubro de 1996 (INPE/MCT).
}

Neste trabalho realizou-se uma climatologia do fenômeno bloqueio no HS, utilizando-se 14 anos de dados do ECMWF (1980-1993). Os resultados mostram quatro regiões preferidas para formação de bloqueios: região da Austrália e Nova Zelândia (Oceano Pacífico), Oceano Atlântico $\left(10^{\circ} \mathrm{W}\right.$ a $\left.70^{\circ} \mathrm{W}\right)$, Oceano Índico $\left(70^{\circ} \mathrm{E}\right.$ a $\left.120^{\circ} \mathrm{E}\right)$ e sudeste do Oceano Pacífico $\left(80^{\circ} \mathrm{W}\right.$ a $\left.120^{\circ} \mathrm{W}\right)$. Esta última é uma região que foi verificada neste estudo como região de formação de bloqueios. Encontrou-se as maiores freqüências de bloqueios no inverno e menores no verão. Observou-se uma acentuada variação interanual de freqüência de bloqueios, principalmente na região da Austrália e Nova Zelândia, encontrando-se as maiores freqüências geralmente em anos de La Niña e menores em anos de EL Niño. Discutiu-se as possíveis causas quanto a variação interanual e a predominância em anos de La Niña. A bifurcação climatológica do vento zonal sobre a região da Austrália e Nova Zelândia é mais forte e melhor definida em anos com maiores frequiências de bloqueios. Observou-se as características de uma situação de bloqueio de longa duração através do estudo de caso, onde este se formou no sudeste do Oceano Pacífico. Os mecanismos físicos de manutenção são discutidos através de fluxos de Eliassen-Palm de sua energética local. Os distúrbios transientes barotrópicos agem para acelerar o fluxo no jato polar e desacelerar na região do bloqueio e na bifurcação do jato de oeste, e assim., manter o bloqueio. A contribuição da interação de três escalas temporais é avaliada através da energética na região do bloqueio. A interação deste fenômeno (componente intrasazonal) com os distúrbios de alta frequiência é relativamente importante, sendo mais relevante a interação do bloqueio com o fluxo sazonal. Visto que o bloqueio extrai energia cinética barotrópica do fluxo difluente sob a influência de um campo de deformação deste fenômeno. A instabilidade baroclínica redistribui esta energia na região do bloqueio.
ATMOSPHERIC BLOCKING IN THE SOUTHERN HEMISPHERE-Atmospheric blocking in the Southern Hemisphere is studied using 14 years (1980-1993) of daily data. Results confirmed the three regions of blocking in winter, viz Pacific Ocean near New Zealand, Indian and Atlantic Oceans. A new region of blocking is found in the Southeast Pacific Ocean. All the preferred regions of blocking show large interannual variations. The interannual variations are large in the New Zealand region. It is found during the La Niña years the blocking frequency in the New Zealand region is more than double of that in El Niño years. The possible causes for this behaviour are explored. It is found that the jet split over New Zealand region is better defined and stronger during the La Niña years than in El Niño years. It is known that the jet split is favorable for formation of blocking highs. This explains why blocking frequency is higher during the La Niña years than in El Niño years. A case study of a long lasting blocking event which occurred in the Southeast Pacific Ocean is performed. The physical mechanisms which maintain this blocking event are explored calculating Eliassen-Palm flux and its local energetics. Transient barotropic disturbances decelerate the jet in the blocking region favoring the split jet character. The contribution of different (time) scales are calculated in maintenance of the energetics of the blocking situation. The interaction of intra-seasonal component with the high frequency component is noted to be very relevant. The role of baroclinic instability is also important. 


\title{
MODELAGEM ESTATÍSTICO-DINÂMICA DE MÉDIA ZONAL INCLUINDO PARAMETRIZAÇÃO EXPLÍCITA DA VEGETAÇÃO
}

\author{
Mário Adelmo Varejão Silva
}

\begin{abstract}
Tese de Doutorado em Meteorologia, orientada pelo Dr. Vadlamudi Brahmananda Rao e pelo Dr. Sérgio Henrique Franchito, aprovada em 20 de novembro de 1996 (INPE/MCT).
\end{abstract}

Um modelo de vegetação, baseado no Biosphere Atmosphere Transfer Scheme (BATS) foi acoplado a um modelo atmosférico estatístico-dinâmico de média zonal, global, utilizando as equações primitivas, para possibilitar simulações, anual e sazonal, do clima médio zonal e de possíveis impactos climáticos gerados por alterações antropogênicas significativas na vegetação. Inicialmente, foram efetuados testes de sensibilidade para aquilatar a resposta do modelo de vegetação aos principais parâmetros intervenientes, considerando-se dois tipos de cobertura vegetal contrastantes: florestas perenifólias e gramíneas baixas. Em seguida, foi testada a habilidade do modelo acoplado em reproduzir a climatologia média zonal observada. Para o cômputo das frações ocupadas por cada tipo de superfície (segundo o BATS), em cada cinturão de latitude, foi usada uma matriz de dados com a vegetação dominante numa grade horizontal de $1^{\circ}$ de latitude por $1^{\circ}$ de longitude. Foram realizados três experimentos de controle na simulação da climatologia média zonal anual $\left(1^{\circ}\right)$ e das médias sazonais de dezembro a fevereiro $\left(2^{\circ}\right)$ e de junho a agosto $\left(3^{\circ}\right)$. Usando a propriedade do modelo acoplado de possibilitar alterações da vegetação em áreas específicas da superfície terrestre, foram realizados experimentos de sensibilidade quanto ao desflorestamento na Amazônia e à desertificação na África. O primeiro consistiu na substituição da floresta tropical perenifólia por gramíneas baixas, na faixa da América do Sul compreendida entre $10^{\circ} \mathrm{N}$ e $10^{\circ} \mathrm{S}$; o segundo na degradação da flora na faixa da África localizada entre $20^{\circ} \mathrm{N}$ e o equador, correspondendo à substituìção de semi-desertos por desertos, de gramíneas altas e arbustos decíduos por semidesertos e, ainda, da floresta tropical perenifólia por gramíneas baixas. Nos experimentos de controle, o modelo acoplado simulou adequadamente as principais características do comportamento da atmosfera, em termos médios zonais, médios anuais ( $1^{\circ}$ experimento) e médios sazonais $\left(2^{\circ}\right.$ e $3^{\circ}$ experimentos). Dentre os experimentos de alteração da flora realizados, os de desmatamento da Amazônia (anual e sazonal) revelaram, quando comparados aos respectivos controles, tendência à redução do fluxo de calor latente para a atmosfera, com o coerente aumento no de calor sensível e incremento na temperatura à superfície.
Decremento na evaporação e na precipitação também foram obtidos. A degradação da flora na Região Norte da África revelou tendências médias anuais semelhantes. Os resultados, em ambos os casos, são comparáveis àqueles oriundos de experimentos congêneres, realizados com mogia, apresentando bons resultados, quando comparados aos dados coletados durante o Rondônia Boundary Layer Experiment 3 (RBLE 3), no contexto do Anglo-Brazilian Amazonian Climate Observational Study (ABRACOS).

\section{STATISTICAL-DYNAMICAL ZONALLY AVERAGED MODEL INCLUDING EXPLICIT} PARAMETERIZATION OF VEGETATION-A biosphere model based on the Biosphere-Atmosphere Transfer Scheme (BATS) was coupled to a primitive equation, global statistical-dynamic zonally averaged model, in order to study the climatic impacts due to possible anthropogenic changes on vegetation. Sensitivity tests were done to verify the vegetation model response to changes on its parameters for both evergreen broadleaf tree and short grass. The coupled model was used to perform three control experiments related to climatological simulation on annual and seasonal mean conditions. In order to realize these experiments a file containing the dominant BATS vegetation type on a $1 \times 1$ grid point was used to calculate the fraction of earth's surface covered by each vegetation/land-cover type, in every latitude belt. Three other experiments were performed to simulate the Amazon region deforestation and Northern Africa desertification effects. The comparison with the control experiments indicated that there was a reduction on the latent heat flux over the perturbed areas and, at the same time, an increase on both sensible heat flux and surface temperature. Decrease in precipitation and evapotranspiration were also obtained. The results were observed to be in good agreement with other experiments done with sophisticated General Circulation Models. Finally the vegetation model was run to simulate mean daily energy fluxes during the dry Amazon season. The results were comparable to those observed during the Rondônia Boundary Layer Experiment 3 (RBLE 3/ ABRACOS). 


\title{
ESTUDO DA ESTRUTURA TERMODINÂMICA DA ATMOSFERA SOBRE A AMAZÔNIA
}

\author{
Alexandre Melo Casseb do Carmo \\ Dissertação de Mestrado em Meteorologia, orientada pelos Drs. Vadlamundi Brahmananda Rao e Sergio Henrique \\ Franchito, aprovada em 25 de novembro de 1996 (INPE/MCT).
}

A estrutura termodinâmica da atmosfera sobre a Amazônia durante os experimentos FLUAMAZON (23/11-21/12/89) e RBLE-3 (13-25/10/94) é estudada no presente trabalho. Tem-se como objetivos estudar o perfil termodinâmico da atmosfera envolvendo a Camada Limite Convectiva (CLC) e a Atmosfera Livre (AL), utilizando-se várias estações ao longo da Região Amazônica; e mostrar as características encontradas sobre cada estação apontando possíveis causas. Os dados de radiossondagens obtidos nestes experimentos são estudados através da análise das variáveis conservativas, sugeridas por Betts (1982). Os resultados obtidos em função do perfil vertical da pressão diferencial de saturação (P), e da estrutura da Linha de Mistura (LM), mostram que a estrutura simples de tripla camada (Camada Sub-Saturada, Camada Saturada e Camada de Entranhamento) da CLC está melhor caracterizada durante o RBLE-3. Referindo-se às estações do FLUAMAZON, sugere-se que as pequenas inversões e os agrupamentos de Pontos de Saturação (PS), observados próximos à superfície, podem ser devido a uma camada estável noturna. Uma forte camada estável encontrada nas estações de Alta Floresta e de Alcântara pode ser devida a downdrafts (corrente descendente) associados a sistemas meteorológicos de mesoescala. Em 0iapóque a presença de uma forte camada estável, em média troposfera, pode estar associada a sistemas meteorológicos de mesoescala e escala sinótica. Em geral, encontrou-se estruturas duplas, na LM, em todas as estações do experimento FLUAMAZON. Sugere-se que os processos combinados de precipitação e evaporação da precipitação foram predominantes na formação destas estruturas. Nota-se também que devido ao aumento do índice pluviométrico, os PSs tornam-se mais próximos entre si, em toda a LM. Associado a isto, a inclinação da LM no diagrama (qe-r) é suavizada, ficando aproximadamente constante em relação a qe. Isto sugere um grande aumento de energia calorífica em toda a coluna atmosférica analisada, devido a intensificação dos movimentos convectivos. $\mathrm{Na}$ AL notou-se que os perfis médios de $\mathrm{P}$, em ambos os experimentos, tendem a um valor comum, pouco maior que P-10 mb. Observa-se, neste estudo, que o nível de origem do ar subsidente no topo da CLC está acima do nível de resfriamento.
STUDY OF ATMOSPHERIC THERMODYNAMIC STRUCTURE OVER AMAZONIA-The atmospheric thermodynamic structure over Amazonia during the FLUAMAZON (23/11 - 21/12/89) and RBLE-3 (13-25/08/ 94) experiments is studied. The main objective of this work is to study the atmospheric thermodynamic profile involving both the convective boundary layer (CBL) and the freeatmosphere (FA). For this purpose several radiosonde stations in the Amazonian region are used. Another objective of the present work is to present characteristics of the atmospheric thermodynamic profile at each station and to discuss the causes for them. The radiosonde data from these experiments are studied using the conservative variable analysis (Betts, 1982). The results, which are obtained as a function of the vertical profile of the differential pressure of saturation $(P)$ and the structure of the mixing line $(M L)$, show that the three-layer simple structure (the sub-saturated layer, saturated layer and entrainment layer) of the CBL is better characterized during the RBLE-3. Regarding the FLUAMAZON data, the small inversions and the grouping of the saturation points (SP), which are observed near surface, are suggested to be due to nocturnal stable layer. The strong stable layer observed in the station of Alta Floresta and Alcantara may be due to downdrafts associated with mesoscale meteorological systems. The strong stable layer observed in the data of Oiapóque, in the middle troposphere, may be associated with mesoscale and synoptic systems. In general, all the radiosonde data of the FLUAMAZON experiment show double structure in the ML. It is suggested that precipitation and evaporation process has a major role in the formation of this structure. Also, it is noted that the PSs are closer in the ML due to the increase of pluviometric index. Consequently, the ML inclination in the (qe-r) diagram is smoothed, becoming almost constant relative to qe. This suggests that there is an increase of the heat energy in the analised atmospheric column due to intensification of the convective movement. It is noted that the mean profiles of $P$ in the FA, in both the experiments, tends to the same value, that is sligthly higher than $P-10 \mathrm{mb}$. In this study, it is observed that the level where the descending air is originated in the top of the CBL is higher than the level of cooling. 


\title{
DESEMPENHO DAS PREVISÕES DE VARIÁVEIS SIMPLES E DERIVADAS OBTIDAS PELO MODELO GLOBAL DO CPTEC/COLA PARA ALGUNS CA- SOS SIGNIFICATIVOS OCORRIDOS SOBRE O CENTRO-SUL DO BRASIL
}

\author{
Daniel Pires Bitencourt
}

Dissertação de Mestrado em Meteorologia, orientada pelos Dr. Prakki Satyamurty, aprovada em 03 de dezembro de 1996 (INPE/MCT)

A introdução de modelos numéricos tornou possível fazer previsão de tempo com melhor confiabilidade e maior prazo de antecedência. A partir de Novembro de 1994, com a inauguração do CPTEC, o Brasil vem realizando previsões operacionais com seu modelo numérico, chamado Modelo Global do CPTEC/COLA. Em busca de melhores resultados é necessário aprimorar este modelo e, para isso, é preciso ter conhecimento do desempenho do mesmo. As estatísticas de desempenho são geralmente obtidas para previsões de variáveis simples, como Altura Geopotencial, Temperatura Virtual, Vento e Umidade Específica. Neste trabalho aplicam-se métodos comuns de estatística para testar o desempenho do modelo para variáveis derivadas, tais como Divergência, Vorticidade, Espessura, Advecção Térmica, Advecção de Vorticidade, Convergência de Fluxo de Umidade, Água Precipitável e Vetor Q. A performance das previsões é testada em quatro estudos de caso. No primeiro caso faz-se uma comparação das previsões realizadas sobre as regiões tropical e extratropical do continente Sulamericano. Os demais estudos de caso destacam as diferenças entre as previsões de variáveis simples e derivadas, assim como a previsibilidade da situação sinótica de cada caso. Através de análise matemática demonstrou-se que, para alguns casos simples e hipotéticos, a correlação entre variáveis simples é diferente da correlação entre variáveis derivadas. Notou se que a onda de menor comprimento contribui mais para o valor da correlação de variáveis derivadas. $\mathrm{O}$ estudo de caso 1 confirma que o modelo apresenta melhor performance sobre os extratrópicos. A previsibilidade nos extratrópicos, em termos da variável geopotencial, é de 96 horas e nos trópicos a previsibilidade, em termos da variável vento, é menos de 48 horas. Com os estudos de caso 2, 3 e 4, observou-se que o vento é melhor previsto para a situação de ciclogênese e que a temperatura é melhor prevista para as situações de geada e neve. Observou-se também, em todos os casos e para todas as variáveis em geral, que a correlação diminui e o erro quadrático médio e o desvio padrão aumentam com o prazo de previsão e, ainda, as previsões de variáveis simples apresentam melhor ou igual performance que as previsões de variáveis derivadas. Um resultado interessante, embora independente, é que a Água Precipitável tem melhor previsibilidade do que a umidade específica, que apresenta previsões úteis somente até 24 horas. Através de comparações visuais entre previsão e análise, conclui-se que
PERFORMANCE OF SIMPLE AND DERIVED VARIABLE FORECASTS OBTAINED BY THE CPTEC/ COLA GLOBAL MODEL FOR SOME SIGNIFICANT CASES OCURRED OVER SOUTH-CENTRAL BRAZIL The Center For Weather Prediction and Climate studies (GFTEC), inaugurated in November 1999, is running operationally a global Numerical Weather Prediction (NWP) model known as CPTEC/GOLA. To obtain increased reliability of weather forecasts it is necessary to estimate the model, and to achieve this, it is necessary to estimate the prediction skill of the model and to study the magnitude and nature of systematic and sporadic errors in the forecasts. Traditionally the performance statistics of the NWP models are calculated by quantitatively comparing the forecast fields and the corresponding analysis fields of simple model variables such a geopotential height at $500 \mathrm{hPa}$. wind components at 850 and $200 \mathrm{hPa}$. In the present study the statistics to test the performance of the model are obtained also with important derived variables, namely, divergence. vorticity, thickness. thermal advection, vortitity advection, water vapor convergence and Q-vector. It is demonstrated, through simple mathematical analysis, that, "anomaly correlation" of a derived variable (such as thermal gradient) is different from that of a simple variable (such as temperature) when the field is composed of more than one number The shorter wave number performance has a larger weight in the anomaly correlation of the composed field of the derived variable. The performance of CPTEC/COLA is tested in four case studies over the South American region. In general, the spatial variability and the root mean square error of the forecast fields increase and the anomaly correlation decreases with the forecast range for all the variables. The derived fields have worse performance statistics than the simple variables. The first case shows the essential differences in the predicability in the extratropics and in the tropics of the region. The other cases provide an idea of the reliability of each of the meteorological variables used for estimating the model performance, and indicate the variables having best predictability for each situation. For the cyclogenesis situation in the southern region of Brazil the wind has the best performance and for the frontal passages and snow occurrence situations the best variable is the surface air virtual temperature. Precipitable water shows a better predictability than the specific humidity at individual levels in the lower troposphere. Visual 
os critérios de validação, apesar de serem simples, foram eficientes no intuito de aprovar ou não as previsões. Isto sugere que tais critérios sejam aplicados a outras situações de tempo, por exemplo, para uma situação de Zona de Convergência do Atlântico Sul. comparisons of the positions and intensities of the synoptic systems in the forecasts and in the corresponding analyses show that the criteria used for the statistical evaluation of the model performance are indeed efficient.

\title{
PADRÕES CLIMÁTICOS DOS VÓRTICES CICLÔNICOS EM ALTOS NIVEIS NO NORDESTE DO BRASIL
}

\author{
Mara Cleofé Valverde Ramírez
}

\section{Dissertação de Mestrado em Meteorologia, orientada pelos Drs. Mary Toshie Kayano e Nelson Jesus Ferreira, aprovada em 04 de dezembro de 1996 (INPE/MCT).}

Neste trabalho foram estudados os padrões de circulação associados aos vórtices ciclônicos de altos níveis (VCAN's) sobre o Nordeste do Brasil e Atlântico Tropical Sul. Utilizaram-se as análises diárias do modelo de previsão de tempo do ECMWF e imagens de satélite meteorológicos. Os resultados climatológicos para o período janeiro de 1980 dezembro de 1989 confirmam que os VCAN's formam-se na alta troposfera, apresentando máxima vorticidade ciclônica em 200 hPa e um centro frio em 300 hPa. A maioria dos VCAN's origina-se sobre o Atlântico Tropical sendo mais freqüentes nos meses de verão. Geralmente os VCAN's estendem-se para baixo até $500 \mathrm{hPa}$, e raramente chegam até $700 \mathrm{hPa}$. Eles inclinam-se com a altura para o oeste, e o centro frio está localizado a leste ou sudeste do centro do vórtice. O tempo de vida médio é de 7,1 dias. Nos anos de "El Niño" os VCAN's são mais profundos na vertical, enquanto nos anos de "La Niña" são confinados nos altos níveis. Confirmou-se que os VCAN's originam-se a partir da amplificação da crista associada a Alta da Bolívia (AB). Essa amplificação pode ser causada pela incursão de sistemas frontais de latitudes médias, ou por cavados do Pacífico Norte ou do Atlântico Norte que se alinham com a AB na direção NW-SE ou NE-SW. Os VCAN's podem ter um deslocamento regular ou irregular. Cavados de latitudes médias associados a sistemas frontais e uma bifurcação interhemisférica a noroeste da América do Sul podem causar deslocamento irregular. Para VCAN's com deslocamento regular é comum observar a presença de um anticiclone nos altos níveis do Atlântico Sul relacionado com a Zona de Convergência do Atlântico Sul. O primeiro modo da análise das Funções Ortogonais Empíricas da vorticidade relativa em $200 \mathrm{hPa}$ apresenta um padrão de ondas estendendo-se desde a costa leste sul americana até o Atlântico Sul com orientação SW-NE. Este modo representa o cavado de latitudes médias, crista amplificada e VCAN, sugerindo que ocorre transferência de momentum e energia na direção SWNE. Para uma área menor inserida no domínio de estudo, o primeiro modo representa o VCAN sobre o oceano e para o segundo modo, o VCAN sobre o Nordeste. Mapas das correlações entre as amplitudes destes modos e as séries temporais da vorticidade relativa filtrada para toda a área de
CLIMATIC PATTERNS OF UPPER LEVEL CYCLONIC VORTEX OVER NORTHEAST BRAZIL-In this work the circulation patterns associated with upper level cyclonic vortices (VCAN's) over the Northeast Brazil and Tropical South Atlantic have been studied. Results from the synoptic climatology for the period January 1980 - December 1989 confirm that VCAN's form in the upper troposphere, with maximum cyclonic vorticity at $200 \mathrm{hPa}$ and a cold core at $300 \mathrm{hPa}$. Most of the VCAN's originate over Tropical Atlantic, and they are more frequent during the summer months. In general the VCAN's extend downward to 500 $h P a$ and rarely they reach $700 \mathrm{hPa}$. They have westward inclination with height and the cold core is located to the east or southeast of their center. The average life time is 7.1 days. During El Niño years, the VCAN's are deeper in the vertical, while during La Niña years they are confined at upper levels. It has been confirmed that VCAN's originate from the amplification of the ridge associated with the Bolivian high (BH). Such amplification can be caused by the incursion of the midlatitude frontal systems, or by troughs in the North Pacific or in the North Atlantic aligned with $\mathrm{BH}$ in NW-SE or NE-SW directions. The VCAN's can present regular or irregular displacements. Midlatitude trough associated with frontal systems and an interhemispheric bifurcation at the northwest of the South America can cause irregular displacement. For VCAN's with regular displacement it was common to observe the presence of a South Atlantic upper level anticyclone which is related to the South Atlantic Convergence Zone. The first mode of the empirical orthogonal function analysis of the relative vorticity at $200 \mathrm{hPa}$ presents a wave like pattern extending from the South American eastern coast towards the South Atlantic with a SW-NE orientation. This mode represents the midlatitude trough, the amplified ridge and the VCAN suggesting that momentum and energy propagation occur in the SW-NE direction. For a small area within the study domain, the first mode represents the VCAN over the ocean and the second mode, the VCAN over Northeast. Maps of correlations between the amplitudes of these modes and the filtered time series of the relative vorticity for the whole area of study indicate a relationship between the South Pacific 
estudo, indicam uma relação entre o cavado do Pacífico Sul $\left(120^{\circ} \mathrm{W}\right.$ e $\left.140^{\circ} \mathrm{W}\right)$ e o padrão de ondas no leste da América do Sul. Assim a presença deste cavado teria alguma contribuição na formação do VCAN. trough $\left(120^{\circ} \mathrm{W}-140^{\circ} \mathrm{W}\right)$ and the wave like pattern over eastern South America. Thus, the presence of this trough might have some contribution on the VCAN formation.

\title{
VARIABILIDADE INTERANUAL DE CAMPOS ATMOSFÉRICOS TOTAIS E ZONALMENTE ASSIMETRICOS
}

\author{
Rita Valéria Andreoli
}

Dissertação de Mestrado em Meteorologia, orientada pela Dra. Mary Toshie Kayano, aprovada em 12 de março de 1998 (INPE/MCT).

A variabilidade interanual de campos atmosféricos totais e zonalmente assimétricos é estudada através de análises de variâncias, padrões de Funções Ortogonais Empíricas (EOF) bem como usando mapas de correlações entre as séries temporais de componentes principais e séries de anomalias filtradas de algumas variáveis, para os periodos de DJF e JJA. 0 período de estudo é de 1979 á 1995. A área de estudo abrange todas as longitudes porém é delimitada latitudinalmente pelos paralelos $80^{\circ} \mathrm{S}$ e $80^{\circ} \mathrm{N}$. Análise de variâncias (total, interanual e suas razões) foram feitas para pressão ao nível do mar (PNM), vento zonal em $200 \mathrm{hPa}$, altura geopotencial em $500 \mathrm{hPa}$, radiação de onda longa (ROL), velocidade vertical em coordenadas de pressão em $500 \mathrm{hPa}$, e temperatura em $925 \mathrm{hPa}$, e para altura geopotencial em $500 \mathrm{hPa}$ assimétrico. Estas análises sugerem que a alta variabilidade nos trópicos está relacionada ao ciclo El Niño-0scilação Sul (ENOS). Sazonalidade é evidente em todos os padrões das variâncias para todas as variáveis, com a máxima variabilidade nas latitudes médias e altas do hemisfério de inverno, exceto para R0L e velocidade vertical. Para essas duas variáveis a variabilidade é pronunciada nos trópicos e durante o verão do HS. 0 primeiro modo de PNM mostra um padrão de onda número um nas regiões tropical e extratropical, que descreve características consistentes com os extremos da 0scilação Sul (OS). 0s padrões de correlação para as outras variáveis mostram diferenças sazonais possivelmente relacionadas a época que se estabelecem os estágios ENOS. As características mais importantes estão relacionadas ao padrão do tipo trem de ondas encontrado nos campos totais e assimétricos de correlação da componente zonal do vento em $200 \mathrm{hPa}$ e da altura geopotencial em $500 \mathrm{hPa}$. Em DJF notam-se, para a componente assimétrica destas variáveis, padrões de trem de ondas na região do Atlântico/África. Em JJA observa-se um padrão de trem de ondas para o vento zona assimétrico no Pacifico Sul. Estas características não são observadas nos correspondentes campos totais. As características distintas para os padrões atmosféricos de campos totais e assimétricos do vento zonal em $200 \mathrm{hPa}$ e altura geopotencial em $500 \mathrm{hPa}$, sugerem que possivelmente a parte assimétrica dessas variáveis desempenha papel importante nas interações das circulações tropical e extratropical.
INTERANNUAL VARIABILITY OF TOTAL AND ZONALLY ASYMMETRIC ATMOSPHERIC FIELDSInterannual variability of total and zonally asymmetric atmospheric fields is studied through analyses of variances and Empirical Orthogonal Function (EOF) patterns as well as using correlation maps between principal component time series and filtered anomalous time series of some variables for DJF and JJA periods. The period of study spans from 1979 to 1995. The domain of the study covers all longitudes but it is latitudinally limitated by the parallels $80^{\circ} \mathrm{S}$ and $80^{\circ} \mathrm{N}$. Variance analyses (total, interannual and their ratios) were done for the total sea level pressure (SLP), zonal wind at $200 \mathrm{hPa}$, geopotential height at $500 \mathrm{hPa}$, vertical velocity in pressure coordinates at $500 \mathrm{hPa}$, outgoing longwave radiation $(O L R)$ and temperature at 925 $\mathrm{hPa}$ and for asymmetric geopotential height at $500 \mathrm{hPa}$. These analyses suggest that the high variability in the tropics is related to El Niño-Southern Oscillation (ENSO) cycle. Seasonality is evident in the variance patterns for all variables, with the highest variability in middle and high latitudes of the winter hemisphere, except for OLR and vertical velocity. For these two variables, highest variability was seen in the tropics and during the austral summer. The first mode of the SLP shows a wavenumber one pattern in the tropical and extratropical regions, which describes features consistent with the extremes in the Southern Oscillation (SO). The correlation patterns for the other variables show seasonal differences possibly related to the periods when the extremes in the SO occur. The most important features are related to wave train pattern found for the total and asymmetry correlation fields of zonal wind at $200 \mathrm{hPa}$ and geopotential height at $500 \mathrm{hPa}$. In DJF, the asymmetric of these variables show a wave train pattern in Atlantic/Africa region. In JJA wave pattern for asymmetric zonal wind at $200 \mathrm{hPa}$ in the South Pacific is observed. The distinct features of the atmospheric patterns of asymmetric and total fields of zonal wind at $200 \mathrm{hPa}$ and geopotential height at $500 \mathrm{hPa}$, suggest that possibly the asymmetric part of these variables plays an important role in the interactions of extratropical and tropical circulations. 


\title{
OBSERVAÇÕES DO BURACO DE OZÔNIO EM PUNTA ARENAS, CHILE
}

\author{
Claudio Angel Rigoberto Casiccia Salgado
}

\begin{abstract}
Dissertação de Mestrado em Geofísica Espacial, orientada pelo Dr. Volker Walter Johann Heinrich Kirchhoff,
\end{abstract} aprovada em 19 de março de 1996 (INPE/MCT).

0 "Buraco" na camada de ozônio é uma realidade para as localidades próximas ao Polo Sul. Durante episódios do fenômeno do buraco da camada de ozônio, na primavera local, a coluna de ozônio pode diminuir em mais de $50 \%$, durante vários dias, e nestas ocasiões, a radiação UV-B, danosa aos seres vivos, aumenta. A região habitada fisicamente mais próxima, da região do buraco, é a cidade de Punta Arenas, Chile, com 100.000 habitantes. Neste trabalho faz-se um levantamento quantitativo da coluna de ozônio em Punta Arenas, resultado de uma colaboração especial entre o INPE e a Universidade de Magallanes, UMAG, desta cidade. O período deste trabalho inclui os anos de 1992, 1993, e 1994. Para obter dados nesta localidade o INPE instalou na UMAG um espectrofotômetro Brewer. A grande vantagem do instrumento Brewer, além de ser um instrumento todo moderno e automatizado, é a sua capacidade de medir radiação UV-B simultaneamente ao ozônio. A partir de dados disponíveis obtidos pelo instrumento TOMS a bordo do satélite Nimbus 7, obteve-se uma climatologia para Punta Arenas. Os dados obtidos em Punta Arenas são comparados com esta climatologia de ozônio de 15 anos. A climatologia obtida dos dados da NASA mostra, globalmente, uma queda na coluna de ozônio entre 1978 e 1992, de 0,4\% por ano. Para a latitude de Punta Arenas, a média anual aumenta para $1,3 \%$ ao ano, considerando as médias do mês de outubro, e de $-0,82 \%$ ao ano, se considerarmos as médias anuais. Isto demonstra claramente que Punta Arenas tem influências fortes relacionadas com o buraco de ozônio da Antártica. Como exemplo de casos extremos de coluna de ozônio muito reduzidas, citamos os dias 27 de setembro de 1993, com 205,9 UD (Unidades Dobson); 5 de outubro de 1992, com 209,3 UD; 17 de outubro de 1994, com 145, 8 UD; e 10 de novembro de 1994, com 204,6 UD. Comprova-se grandes aumentos de radiação UV-B por ocasião das reduções de ozônio. No entanto, os valores excepcionais observados nestas ocasiões ainda não são maiores do que os valores normais medidos no período do verão, e são menores também do que níveis normalmente observados na estação de baixa latitude Natal ( $\left.6^{\circ} \mathrm{S}\right)$, no Brasil.
OBSERVATIONS OF OZONE HOLE AT PUNTA ARENAS, CHILE-The ozone "hole" is a reality for locations near the South Pole. During episodes of the ozone hole, in the southern Spring, the ozone column may become depleted by as much as $50 \%$ during several days, and during these occasions, the $U V-B$ radiation increases. The largest populated area closest to the ozone hole region is the city of Punta Arenas, Chile, with about 100,000 inhabitants. This work describes the ozone column over Punta Arenas as a result of a collaboration program between the local University of Magallanes and INPE. The interval of this study covers the years of 1992, 1993, and 1994. In order to obtain ozone data in Punta Arenas, INPE installed a Brewer spectrophotometer at the UMAG campus. The great advantage provided by the Brewer instrument is that it measures also de $U V-B$ radiation, in addition to being totally automatic. The ozone data obtained in Punta Arenas are compared with an ozone climatology of 15 years, obtained from data by the TOMS instrument developed by NASA for measurements from the Nimbus 7 satellite. Between 1978 and 1992 the global average decay of the ozone column (the global ozone trend) is $-0.4 \%$ per year; using the data for Punta Arenas, this trend becomes $-0.82 \%$ per year using the yearly averages, and $-1.3 \%$ per year, using the October averages. This clearly shows that Punta Arenas is strongly influenced by the Antarctic Ozone Hole. Low ozone column examples were observed on 27 September 1993, with 205.9 DU (Dobson Units); 5 October 1992, with 209.3 DU; 17 October 1994, with 145.8 DU; 10 November 1994, with 204.6 DU. Large variations of $U V-B$ are seen on these occasions. However, the excepcional values observed under these circumstances are still not larger than the normal values observed during summer; they are also lower than the normal summer values observed for example at the low latitude station Natal ( $\left.6^{\circ} S\right)$, in Brazil. 


\title{
O PERFIL DE TEMPERATURA NA REGIÃO DA MESOPAUSA EM SÃO JOSE DOS CAMPOS $\left(23^{\circ} \mathrm{S}, 46^{\circ} \mathrm{O}\right)$ OBTIDO COM RADAR DE LASER
}

\author{
Maria Paulete Pereira Martins Jorge
}

Tese de Doutorado em Geofísica Espacial, orientada pelo Dr. Barclay Robert Clemesha, aprovada em 17 de dezembro de 1996 (INPE/MCT).

Esta tese trata da obtenção do perfil de temperatura atmosférica entre 80 e $100 \mathrm{~km}$ de altura, região da mesopausa. Ela baseia-se no desenvolvimento e aprimoramento de uma técnica experimental simples que permite determinar a temperatura da atmosfera utilizando um radar de laser e as propriedades físicas do sódio mesosférico. A técnica utiliza o radar sintonizado na linha $\mathrm{D}_{2}$ do sódio (5890 ̊) com um interferômetro Fabry-Perot substituindo o espelho de saída do laser. O Fabry-Perot possui um "free-spectral-range" de 0,0198 ^, cujo valor é o mesmo da separação da estrutura hiperfina de linha $\mathrm{D}_{2}$ do sódio. Inicialmente um controlador de temperatura permite variar a temperatura do Fabry-Perot e realizar uma varredura em comprimento de onda na estrutura hiperfina do sódio. Posteriormente um Fabry-Perot controlado por pressão permite mudar o comprimento de onda do laser do máximo para o mínimo da estrutura hiperfina. A temperatura do sódio, ou da atmosfera, uma vez que estão em equilíbrio termodinâmico, é inferida da convolução entre o perfil do laser e o perfil ressonante do sódio. Os resultados obtidos são comparados com as medidas de temperatura rotacional do $\mathrm{OH}$ e do $\mathrm{O}_{2}$ fornecida por fotômetros situados em Cachoeira Paulista.
THE TEMPERATURE PROFILE IN THE MESOPAUSE REGION AT SÃO JOSÉ DOS CAMPOS $\left(23^{\circ} S, 46^{\circ} O\right)$ OBTAINED WITH LIDAR -This thesis is about the acquisition of the temperature profile between 80 and 100 $\mathrm{km}$, in the mesopause region. It is based on the development and improvement of a simple experimental technique that enables to determine the atmospheric temperature using a lidar and the physical properties of the mesospheric sodium. The technique consists in a lidar tuned in the $D_{2}$ line of the sodium (5890 $\AA$ ) and the output mirror of the laser replaced by a Fabry-Perot interferometer. The Fabry-Perot interferometer has the free-spectral-range of $0.0198 \AA$, same value of the separation between the hyperfine components of the $D_{2}$ line. Inicially a temperature controller permits to vary the Fabry-Perot temperature and to do a wavelength sweeping in the hyperfine structure of the sodium. Subsequently a Fabry-Perot with pressure control enables to change the laser wavelength between the maximun and the minimun of the hyperfine structure. The sodium, and the atmospheric temperature, once they are in thermodynamic equilibrium, are deduced from the convolution between the laser spectrum and the sodium ressonance profile. The results are compared with the $\mathrm{O}_{2}$ and $\mathrm{OH}$ rotational temperature obtained at Cachoeira Paulista by photometer.

\section{ESTUDO DE PARÂMETROS DE ONDAS DE GRAVIDADE POR MEDIDAS SIMULTÂNEAS DE RADAR MU E FOTOMMETRO EM SHIGARAKI $\left(35^{\circ} \mathrm{N}, \mathbf{1 3 6}^{\circ} \mathrm{L}\right)$, JAPÃO}

\section{Ricardo Arlen Buriti da Costa}

Tese de Doutorado em Geofísica Espacial, orientada pelos Drs. Hisao Takahashi e Paulo Prado Batista, aprovada em 14 de março de 1997 (INPE/MCT).

O presente trabalho tem como objetivo calcular parâmetros (comprimento, período, velocidade de propagação etc.) de ondas atmosféricas a partir de observações simultâneas de dados de intensidade e temperatura rotacional da aeroluminescência (ou airglow) do $\mathrm{OH}(6,2)$, observado pelo fotômetro FOTOH, e dados de vento observado pelo radar MU na região da mesopausa (entre 80 e $100 \mathrm{~km}$ ) em Shigaraki $\left(35^{\circ} \mathrm{N}, \sim 136^{\circ} \mathrm{L}\right)$, Japão. A determinação dos parâmetros físicos destas ondas permite obter informações a respeito da sua propagação pela atmosfera além de aumentar o conhecimento sobre a interação destas ondas com
STUDY OF THE WAVE PARAMETERS BY SIMULTANEOUS MEASUREMENTS USING MU RADAR AND PHOTOMETER AT SHIGARAKI $\left(35^{\circ} \mathrm{N}\right.$, $\left.136^{\circ} \mathrm{E}\right), \mathrm{JAPAN}$-The goal of this thesis is to calculate some parameters, such as horizontal and vertical wavelength, observed and intrinsic periods, velocity of propagation, etc., of atmospheric waves by simultaneous observations of intensity and rotational temperature of $\mathrm{OH}(6,2)$ by a scanning photometer and winds near the mesopause (between 80 and $100 \mathrm{~km})$ by MU radar, at Shigaraki $\left(35^{\circ} \mathrm{N}\right.$, $\left.136^{\circ} \mathrm{E}\right)$, Japan. These parameters lead us to know about 
o airglow. As observações ocorreram em novembro de 1994 e de julho a setembro de 1995. O fotômetro foi construído no laboratório Lume/INPE e tem como principal característica a possibilidade de fazer medidas em 8 posições do céu com resolução temporal de 6 minutos. O radar MU consiste de 475 antenas distribuídas dentro de uma área circular de $108 \mathrm{~m}$ de diâmetro. No modo meteórico, o radar mede o vento a partir de traços ionizados por meteoros ao entrar na atmosfera terrestre. Os resultados das análises das observações mostraram que vários dias apresentaram ondas propagando-se pela atmosfera e que foi possível determinar alguns de seus parâmetros. As ondas caracterizadas neste trabalho ficaram compreendidas entre 500 e $2960 \mathrm{~km}$ de comprimento horizontal e o período entre 3,5 e 9,5 h. Outros parâmetros determinados experimentalmente, tais como, velocidade, comprimento de onda vertical, estavam consistentes com modelos para ondas de gravidade. Alguns resultados mostraram que a diferença entre período observado e período intrínseco eram praticamente iguais, porém, a noite de 29/07/95 apresentou uma diferença de quase $100 \%$. Para duas noites analisadas, foi determinado também, a presença de duas ondas superpostas, mas, com características bem distintas. A noite do dia, e.g., 04/11/94 mostrou a presença de uma onda de curto período (3 horas) superposta a uma outra de longo período (9 horas). Foi observado uma diferença de fase entre a intensidade e a temperatura rotacional em torno de 1,5 horas para as noites de 04/11/94 e 08/11/94. the propagation of these waves through the atmosphere, besides the interaction between airglow and waves. The observations were carried out in November, 1994 and from July to September, 1995. The photometer was built at Lumel INPE laboratory and its main objective is to measure the intensity and temperature in 8 positions (azimuths) of the sky with 6 minutes of temporal resolution. The MU radar is an array of 475 antennas inside a circular area with a diameter of $108 \mathrm{~m}$. The meteor mode permits to measure wind by tracing movement of a meteor ionized line which is formed by the entrance of a meteoroid in the atmosphere. From the analysis of the nocturnal variations of both the airglow and wind data, waves propagating through the atmosphere were seen and the physical parameters were determined. The waves determined in the thesis were in the range from 500 to $2960 \mathrm{~km}$ of horizontal wavelength and from 3.5 to 9.5 hours of period. Under normal circumstances, the difference in period between observed and intrinsic, as wind informations were present, was small, but, in one of the nights observed, this difference was of about 100\%. In one of the nights (Nov. 04, 1994) analised, a gravity wave was identified with the period of 9 hours and a short period (3 hours) wave superposed on the long period wave.

\title{
OBSERVAÇÕES DA RADIAÇÃO UV-B EM PUNTA ARENAS - CHILE E EFEI- TOS DO BURACO NA CAMADA DE OZÔNIO
}

\section{Félix de la Cruz Zamorano Banda}

\author{
Dissertação de Mestrado em Geofísica Espacial, orientada pelo Dr. Volker Walter Johann Heinrich \\ Kirchhoff, aprovada em 26 de março de 1997 (INPE/MCT).
}

Medições da coluna total de ozônio e da radiação UV-B (280 - $320 \mathrm{~nm}$ ) estão sendo realizadas desde julho de 1992 em Punta Arenas, Chile, num esforço conjunto entre a Universidade de Magallanes - UMAG, Chile e o Instituto Nacional de Pesquisas Espaciais - INPE, Brasil. Punta Arenas é uma cidade de aproximadamente 100.000 habitantes, que se encontra em uma região perto da Antártica $\left(53,2^{\circ} \mathrm{S}\right.$, $\left.70,9^{\circ} \mathrm{W}\right)$, onde o buraco na camada de ozônio aparece já há vários anos com o início da primavera austral. A partir de outubro de 1992 tem-se observado em alguns dias a passagem do buraco de ozônio sobre esta região, registrando-se níveis muito baixos de ozônio de até 145,8 UD (Unidades Dobson) em outubro de 1994. Cada vez que o buraco apareceu na região de Magallanes, os níveis da radiação UV-B aumentaram de modo considerável. Neste trabalho faz-se um estudo quantitativo da radiação UV-B a fim de avaliar
OBSERVATIONS OF UV-B RADIATIONS AND EFFECTS OF OZONE "HOLE" IN PUNTA ARENAS CHILE-Regular measurements of total ozone and $U V-B$ (280-320 nm) radiation are being carried out since July 1992 at Punta Arenas $\left(53.2^{\circ} \mathrm{S}, 70.9^{\circ} \mathrm{W}\right)$, Chile, in a collaborative project between the University of Magallanes - UMAG, Punta Arenas, Chile and the National Institute for Space Research - INPE, Brazil. Punta Arenas city has a population of about 100,000 inhabitants and is located close to the Antarctic region, where during the last several years an "ozone hole" has been observed in Spring. The total ozone observations at Punta Arenas have shown the presence of an ozone hole on some days during the month of October, every year since 1992, with values as low as $145.8 \mathrm{DU}$ (Dobson Units) in October 1994. Every time an ozone hole appears over this region, there is a considerable increase 
estes incrementos e compara-se com medições feitas em outras localidades. As medições foram obtidas utilizando principalmente o espectrofotômetro Brewer, instrumento que tem a capacidade de medir a coluna total de ozônio e a radiação UV-B que atinge a superfície. Os dados de UV-B de Punta Arenas mostram um incremento desta radiação de até 109\% no dia 04 de outubro de 1992, ocasião na qual o ozônio total diminuiu 33\% em relação à média móvel $(\mathrm{n}=17)$. Em 1993, a radiação UV-B aumentou $70 \%$ no dia 27 de setembro quando a quantidade total de ozônio diminuiu $26 \%$, enquanto no ano 1995 o incremento da radiação UV-B foi de $94 \%$ no dia 12 de outubro quando, por ocasião da passagem do buraco sobre a região, a quantidade total de ozônio diminuiu 30\%. A análise espectral das intensidades de radiação UV-B nos dias antes assinalados mostram um maior aumento na faixa de comprimentos de onda entre 295 e 297 $\mathrm{nm}$, sendo de até 35 vezes maior do que em dias do mesmo mês nos quais as condições de ozônio são "normais". Na faixa de comprimentos de onda entre 295 e $300 \mathrm{~nm}$ produzse maior incremento das intensidades ponderadas pelos espectros de ação do Eritema, DNA e dano em Plantas, sendo na média de 4 até 7 vezes maior que na faixa de 300 até 315 $\mathrm{nm}$ No entanto, os valores aumentados de LTV-B observados, não são ainda maiores aos registrados nos meses de verão em Punta Arenas, e são também menores que os observados em Natal $\left(5,8^{\circ} \mathrm{S}, 35,2^{\circ} \mathrm{W}\right)$, Brasil. in $U V-B$ radiation. A study of $U V-B$ radiation enhancements during ozone hole conditions at Punta Arenas has been carried out and compared with measurements at other locations. The measurements were obtained with a Brewer spectrophotometer, which can measure both the total ozone and $U V$ - $B$ radiation reaching the earth's surface. The $U V$ $B$ data show an increase of up to $109 \%$ on October 4, 1992, when the total ozone showed a decline of $33 \%$ in relation to the running average $(n=17)$. In 1993, the $U V-B$ radiation increased by $70 \%$ on September 27, when the total ozone decreased by 26\%, whereas in 1995, the UV-B increase was $94 \%$ on October 12; when the ozone hole passed over the region, with a total ozone decrease of $30 \%$. The spectral variations of the $U V-B$ radiation intensities show an enhancement of up to 34 times in the region of 295 to 297 $n m$ on the above mentioned days compared with the days when the total ozone levels are considered normal. The Erythema, DNA and Plants Action Spectnnn weighted intensities in the wavelength region 295 to $300 \mathrm{~nm}$ are 4 to 7 times larger when compared with the wavelength region 300 to $315 \mathrm{~nm}$. It should be emphasized that the higher levels of the LTV-B radiation during ozone hole conditions are not larger than those observed during summer months and are also lower compared with Natal $\left(5.8^{\circ} \mathrm{S}, 35.2^{\circ} \mathrm{W}\right)$,

\title{
RESPOSTA DO SISTEMA IONOSFERA-TERMOSFERA A TEMPESTADES MAGNÉTICAS NO SETOR SUL-AMERICANO
}

\author{
Ximena Andrea Torres Pincheira
}

Tese de Doutorado em Geofísica Espacial, orientada pelos Drs. Inez Staciarini Batista e Mangalathayil Ali Abdu, aprovada em 29 de abril de 1998 (INPE/MCT).

Apresenta-se um estudo de casos de tempestade magnética ocorridos em anos de mínima e máxima atividade solar para uma rede de estações no setor sul-americano: em baixas (Fortaleza, FZ, e Cachoeira Paulista, CP), médias (Concepción, CON) e altas (Ilha Rei Jorge, IRJ) latitudes. Propõe-se estudar as inter-relações do sistema ionosfera-termosfera e caracterizar os processos físicos causantes dos distúrbios neste setor, onde a configuração do campo geomagnético apresenta forte variabilidade do ângulo de declinação magnética e da intensidade do campo. Esperam-se respostas do sistema com algumas dependências latitudinais e longitudinais. Estuda-se a propagação dos ventos termosféricos perturbados e as causas das fases negativas em foF2 com dados de ionossonda e com ajuda do modelo FLIP (Field Line Interhemispheric Plasma). Encontra-se que as tempestades desenvolvidas no mínimo solar produzem efeitos maiores sobre a ionosfera que aquelas desenvolvidas no máximo solar. Os efeitos sazonais prevalescem sobre os de ciclo so-
IONOSPHERE-THERMOSPHERE RESPONSE TO MAGNETIC STORMS ON THE SOUTH-AMERICAN REGION-We show case study of magnetic storm events during low (1986) and high (1989-1990) solar activity years using a chain of ionospheric South American stations in low (Fortaleza, FZ, and Cachoeira Patilista, CP), mid (Concepción, CON) and high (Ilha Rei Jorge, IRJ) latitudes.We study the ionosphere - thermosphere system inter-relation during those periods and describe the physical processes causing disturbances in a region, where the magnetic field configuration shows high declination angle and field intensity variability. We investigate the responses of the ionosphere - thermosphere system to the disturbance and we expect to find some latitudinal and longitudinal dependencies. We study disturbed thermospheric wind pattern and the negative phases in foF 2 using ionosonde data and the FLIP Model (Field Line Interhemispheric Plasma Model). Ionospheric effects of magnetic storm are higher 
lar em altas latitudes. Os padrões modelados de ventos acompanham as mudanças de $h_{\max }$ e são de magnitude maior em médias latitudes. Observa-se claramente a propagação de perturbações nos ventos associada ao início de sub-tempestades. Existe uma série de fatores locais que induzem mudanças na ionosfera durante a propagação latitudinal e longitudinal dos distúrbios: em IRJ predominam as fases negativas, causadas por mudanças na composição da atmosfera neutra, diminuições em $[\mathrm{O}] /\left[\mathrm{N}_{2}\right]$ podem ser de até $80 \%$. Sobre CON, as fases negativas não podem ser completamente explicadas por efeitos de composição; nesta estação de médias latitudes a ação dos ventos é mais efetiva e é a que determina o comportamento de $\mathrm{h}_{\max }$. Em CP, campos elétricos e ventos zonais também influenciam em forma importante $\mathrm{h}_{\max }$. during solar minimum than during solar maximum conditions. Seasonal effects are more important than solar cycle effects at high latitudes. The modeled wind patterns have the same variation as $h_{\max }$ and their magnitudes are higher at mid latitudes. We see a clear perturbed wind propagation associated with the onset of sub-storms. There are a series of local factors that can induce also changes in the ionosphere, during latitudinal and longitudinal propagation of a magnetic storm disturbance. The negative phases in foF 2 over IRJ are caused by neutral atmosphere composition changes (the variation in the ratio $[\mathrm{O}] /\left[\mathrm{N}_{2}\right]$ can be as high as $80 \%$ ). In CON, the negative phases can not be completely explained by neutral atmosphere changes. In this middle latitude station, wind action is more effective to determine the $h_{\max }$ variations. In CP, electric fields and zonal winds are both very important for the $h_{\max }$ variations.

\title{
MODELAGEM IONOSFÉRICA EM BAIXAS LATITUDES NO BRASIL
}

\author{
Jonas Rodrigues de Souza \\ Tese de Doutorado em Geofísica Espacial, orientada pelos Drs. Mangalathayil Ali Abdu e Inez \\ Staciarini Batista, aprovada em 27 de maio de 1997 (INPE/MCT).
}

Neste trabalho, o modelo ionosférico SUPIM (Sheffield University Plasmasphere-Ionosphere Model) é utilizado para calcular os parâmetros ionosféricos foF 2 e hmF2, e os resultados do modelo são comparados com dados de ionossondas registrados em Huancayo, Peru, em Fortaleza e em Cachoeira Paulista, Brasil. Os parâmetros de entrada do SUPIM, tais como, fluxo solar EUV (Extremo UltraVioleta), campos elétricos e ventos termosféricos são então ajustados para que os resultados do modelo concordem com as observações. O estudo para Huancayo, o qual é feito para equinócio de atividade solar máxima, mostra que o fluxo solar EUV fornecido pelo modelo desenvolvido por Tobiska (1991) superestima o valor deste parâmetro em $40 \%$ e destaca a importância do uso das derivas da mesma época que os dados ionosféricos a serem estudados por modelagens. A parte mais importante deste trabalho é um estudo da região $\mathrm{F}$ ionosférica na região do Brasil usando o modelo SUPIM e dados de h'F, foF2 e hmF2 registrados simultaneamente em Fortaleza e em Cachoeira Paulista. Neste estudo são calculados a deriva equatorial $\mathbf{E} \mathbf{x} \mathbf{B}$, o fluxo solar EUV, foF2, hmF2 e ventos termosféricos meridionais. Estes parâmetros são calculados para períodos geomagneticamente calmos e para atividade solar mínima e máxima. Para cada nível de atividade solar é analisado o comportamento da região $\mathrm{F}$ durante verão e inverno. $\mathrm{O}$ fluxo solar EUV, produzido pelo modelo do Tobiska (1991), apresenta resultados inconsistentes apenas para verão de
IONOSPHERIC MODELLING AT LOW LATITUDES IN

BRAZIL-In this work, the ionospheric model SUPIM (Sheffield University Plasmasphere-lonosphere Model) is used to calculate the ionospheric parameters foF 2 and $\mathrm{hmF} 2$, and the model results are compared with ionosonde data recorded at Huancayo, Peru, at Fortaleza and Cachoeira Paulista, in important part of this work is a study of the ionospheric F region over Brazil using SUPIM and $h$ ' $F$, foF 2 and $\mathrm{hmF} 2$ data recorded simultaneously at Fortaleza and at Cachoeira Paulista. In this study, equatorial $\boldsymbol{E} x \boldsymbol{B}$ dfift, foF 2 , hmF2 and meridional thermospheric winds are calculated for geomagnetically calm periods and also for minimum and maximum solar activity conditions. For each solar activity level the $F$ region behaviour during summer and winter is examined. The solar EUV flux using Tobiska (1991) model shows inconsistent result only for summer of minimum solar activity, indicating an underestimate of his flux values by 25\%. The South Atlantic Anomaly effects in the ionosphere over Cachoeira Paulista are also taken into account in the SUPIM code, and the results indicate a seasonal variation with negligible effect during the winter. At Fortaleza, the parameters foF 2 and $h m F 2$ show sensitive variation due to changes in $\boldsymbol{E} x \boldsymbol{B}$ drift. But, between 07:00-15:00 LT, the parameter $\mathrm{hmF} 2$ is also strongly controlled by combination of the winds and drifts. At Cachoeira Paulista, the local winds control hmF2. Also we verify that foF 2 at this station shows significant dependence on the winds at magnetic 
atividade solar mínima, com valores subestímados em $25 \%$. São incluídos os efeitos da Anomalia do Atlântico Sul sobre a ionosfera de Cachoeira Paulista no código do modelo SUPIM e os resultados mostram que estes efeitos apresentam variações sazonais, sendo desprezíveis durante inverno. Em Fortaleza, os parâmetros foF2 e hmF2 apresentam sensíveis variações devido às mudanças da deriva $\mathbf{E} \mathbf{x} \mathbf{B}$. Mas, entre 07:00-15:00 horas, o parâmetro hmF2 também é fortemente controlado pela combinação de ventos e deriva. Em Cachoeira Paulista, os ventos locais controlam hmF2. Também sobre essa estação, constatamos que foF2 apresenta dependência significante dos ventos no seu ponto conjugado. É apresentado um estudo comparativo entre os ventos calculados neste trabalho (ventos ajustados), os ventos do modelo HWM9O, os ventos calculados por Medeiros (1995) e os dados de ventos obtidos pelo método de interferometria de Fabry-Perot. Os resultados mostram boa concordância dos ventos ajustados com os dados observados em Cachoeira Paulista e também mostram boa concordância com os resultados de Medeiros (1995) durante a tarde e à noite, exceto, durante inverno de atividade solar mínima. Analisando as variações de foF2 com a latitude e com a hora local constatamos que a intensidade máxima do pico da Anomalia Equatorial forma-se mais cedo na hemisfério de inverno do que no hemisfério de verão. conjugate point of Cachoeira Paulista. Comparative study of the calculated winds in this work (adjusted winds), the HWM90 model winds, the calculated winds by Medeiros (1995) and the winds data recorded by Fabry-Perot interferometer at Cachoeira Paulista is also done. The results show good agreement of the adjusted winds with the observed data and also show good agreement with the model of Medeiros (1995) during the evening and the night, except, during the winter of minimum solar activity. Analysing foF 2 variation with the latitude and with the local time we verify that the Equatorial Anomaly peak reaches maximum intensity earlier in the winter hemisphere than in the summer hemisphere.

\title{
PUBLICAÇÃO DE TESES E DISSERTAÇÕES
}

\author{
Para a publicação de Teses e Dissertações na Revista Brasileira de Geofísica, favor \\ enviar uma cópia em papel e em disquete, com os títulos e resumos em português \\ ou espanhol, e em inglês, ambos contendo um máximo de 500 palavras.
}

Incluir nome do autor(a), do orientador(a), departamento e universidade, título obtido, e data da defesa. Não incluir referências ou ilustrações. 


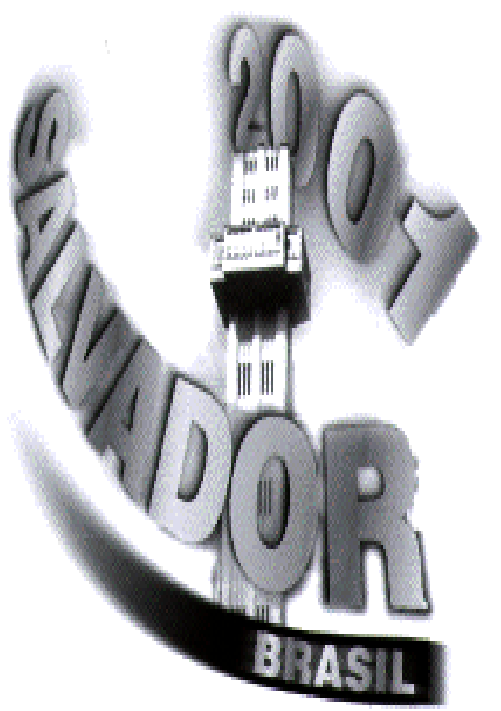

\section{SALVADOR 2001: COME TO SEE WHAT'S NEW IN BRASIL}

\section{BALL FOR PAPERS}

$7^{70}$ Congresso Internacional da Sociedade Brasileira de Geofisica

7 th International Congress of the Brazilian Geophysical Society

Salvador, Brasil

The Technical Program will include oral sessions and poster sessions on exploration and environmontal applications of seismic, potential fields, borehole, nuclear and geologic methods, as well as solid earth and space geophysics, instrumentation and case histories. The deadline for expanded abstracts is March 31, 2001 (maximum four pages including figures). For Absiract Kits with detailed insiructions and standard sheets, contactthe SBGf Business Oftice:

\section{SBGf Business Office}

Rua Caetano de Moura, 123 - Federação

Salvador, Bahia, Brazil

Phone/Fax:(55)(71)235-0002

E-mail: cisbgf@sbgf.org.br

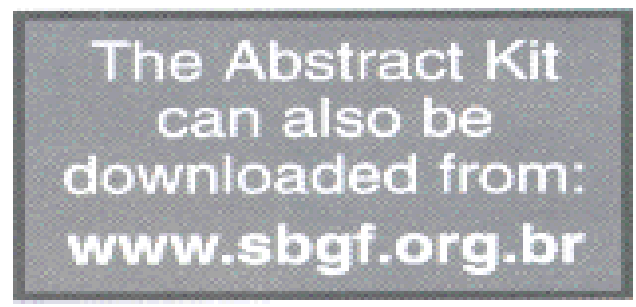

The Salvador 2001 International Congress is sponsored by The Brazilian Geophysical Society (SRGt), the Society ot Exploration Geophysicisis (SEG), The European Association of Geoscientists and Engineers (EAGE), and the Latin American Geophysical Union (ULG). Everyone is invited to participate in this important International Congress (Conference and Exposition).

Exposition Prospectus - For all potential exhibitors, Salvador 2001 will otfer a iruly outstanding marketing opportunity for all of Latin America. Special invitations will also be extended to all stateowned and private resource companies to attend and participate, Companies wishing to receive additional exhibitor information should contactthe SBGf. 